Научная статья

УДК 34:616

DOI 10.18101/2658-4409-2021-2-26-30

\title{
К ВОПРОСУ О СОВЕРШЕНСТВОВАНИИ ЗАКОНОДАТЕЛЬСТВА В СФЕРЕ ЗДРАВООХРАНЕНИЯ
}

\author{
(C) Богодухов Никита Андреевич \\ магистрант, \\ Бурятский государственный университет имени Доржи Банзарова \\ Россия, 670000, г. Улан-Удэ, ул. Сухэ-Батора, 6 \\ nikisbog@yandex.ru
}

\begin{abstract}
Аннотация. В настоящей статье автор анализирует сложившуюся судебную практику по компенсации морального и материального вреда вследствие медицинской ошибки. Проведен сравнительно-правовой анализ аналогичных дел в иностранных государствах. В ходе исследования была обнаружена закономерность между существованием института обязательного страхования профессиональной ответственности и уровнем компенсации морального вреда. С целью диахронного исследования проблемы, был изучен ряд законопроектов, которые до настоящего времени находятся в разработке. Особое внимание уделено более ранним научным публикациям, так как поставленная в работе проблема разрабатывается достаточно давно и ее решение многие юристы видят одинаково. Принимая во внимание мнение отдельных ученых указывается на необходимость издания федерального закона, закрепляющего обязанность страхования медицинскими работниками своей профессиональной ответственности и регулирующего возникающие в связи с этим отношения.

Ключевые слова: медицинское право, страхование, профессиональная ответственность, медицинские работники, моральный вред, компенсация вреда, медицинские учреждения, страховое право, медицинское учреждение, законопроект
\end{abstract}

\section{Для цитирования}

Богодухов Н. А. К вопросу о совершенствовании законодательства в сфере здравоохранения // Вестник Бурятского государственного университета. Юриспруденция. 2021. Вып. 2. С. 26-30.

Статья 41 Конституции Российской Федерации гласит, что каждый имеет право на охрану здоровья и медицинскую помощь ${ }^{1}$. Трудно переоценить значение этой конституционно-правовой нормы для граждан Российской Федерации, ведь уровень оказания медицинской помощи является ключевым критерием оценки качества жизни населения. Медицинская деятельность всегда сопряжена с большим риском как объективного, так и субъективного характера.

Это обусловлено спецификой данного вида деятельности, в котором детерминирующим фактором неблагоприятного исхода могут стать как индивидуальные особенности человеческого организма, так и некомпетентность медицинского персонала.

В рамках нашей научной статьи мы обратимся именно к субъективному фактору. Ведь граждане, столкнувшиеся проблемой некачественного оказания медицинской

1 Конституция Российской Федерации принята всенародным голосование 12 декабря 1993 года // СПС «КонсультантПлюс». Текст : электронный. 
помощи или с некорректным поведением либо равнодушием со стороны работников медицинского учреждения, желают восстановить свои нарушенные права.

Следует отметить, что действующее российское законодательство содержит достаточное количество правовых инструментов для восстановления нарушенных интересов граждан. Однако они не всегда отличаются особой эффективностью. Давайте рассмотрим их поподробнее.

Первый вариант — для граждан, обладающих определенным уровнем правовых знаний. Это обращение с исковым заявлением о возмещении морального и материального вреда в суд. Данный способ отличается значительными процессуальными трудностями, связанными в первую очередь со сбором доказательств и проведением экспертизы качества оказанной медицинской помощи. Как правило, суды не так часто удовлетворяют требования граждан, а если и удовлетворяют, то в части компенсации морального вреда суммы возмещения остаются достаточно маленькими. Кроме того, в случае неудовлетворения требований истца на него ложатся процессуальные издержки, связанные с привлечением юристов и проведением дорогостоящих экспертиз.

Второй вариант - обратиться в надзорные и контрольные органы, которых в сфере здравоохранения более чем достаточно (начиная от прокуратуры и заканчивая региональными министерствами и департаментами). Такие проверки в большинстве своем заканчиваются лишь констатацией фактов нарушения и привлечением отдельных лиц к дисциплинарной, административной, в крайне редких случаях к уголовной ответственности. При этом восстановлению нарушенных прав граждан данные меры мало способствуют.

Третий вариант - обращение в правоохранительные органы для привлечения медицинских работников именно к уголовной ответственности. Однако не всегда действия врачей или иного персонала подпадают под состав уголовных статей. И данная мера может стать эффективной лишь в редких случаях, когда сомнений в преступности деяния не остается.

Как мы можем заметить, из всего многообразия правовых инструментов лишь один в наибольшей мере удовлетворяет нарушенные права граждан - это возмещение морального и материального вреда в судебном порядке.

Ведь пострадавшим от врачебной ошибки далеко не всегда важно наказать некомпетентного сотрудника, гораздо важнее восстановить потерянное здоровье, материальные ресурсы и время. Все это возможно путем значительных денежных затрат. Но, как мы уже отмечали, суды не стремятся к присуждению крупных сумм в счет компенсации вреда.

К примеру, по делу Пержинской Е.С. к ГБУ РС(Я) «Мирнинская ЦРБ».

В течение нескольких дней сотрудники медицинского учреждения не могли установить диагноз и организовать лечение малолетней дочери гражданки Пержинской. У ребенка длительное время была повышенная температура, острые боли и кровоизлияния.

После чего, не имея возможности получить качественную помощь в Якутии, девочку отправили в Новосибирск, где она была срочно госпитализирована. Решением Мирнинского районного суда Республики Саха (Якутия) с ГБУ РС(Я) 
«Мирнинская ЦРБ» было взыскано 100000 рублей в качестве компенсации морального вреда ${ }^{1}$.

По делу Задворовой Натальи Викторовны к БУ «Мегионская городская больница № 1». Судом установлены факты несвоевременного и ненадлежащего оказания медицинской помощи пациенту дежурным терапевтом, который не назначил полное обследование больному, не проконтролировал исполнение своих назначений.

В результате муж гражданки Задворовой скончался. Мегионский городской суд взыскал в ее пользу 750000 p. $^{2}$

Несмотря на тяжесть физических и нравственных страданий, судом были присуждены чрезвычайно маленькие денежные суммы. Данный факт становится очевидным в сравнении с другими государствами. В США компенсация морального вреда вследствие врачебных ошибок находится в диапазоне 200 000-300 000 долл. В Великобритании травма челюсти оценивается в 6250 евро ( $\approx 40000$ р.).

В защиту российских судов хотелось бы отметить, столь низкие суммы компенсации морального вреда можно объяснить тем фактом, что взыскиваться они будут с «не столь богатых» медицинских работников. Несмотря на то, что иски подаются к медицинским учреждениям, все выплаты, произведенные данными организациями, возмещаются из средств виновных в причинении вреда работников.

Данное правило следует из п. 1 ст. 1080 ГК РФ, согласно которому лицо, возместившее вред, причиненный другим лицом (работником при исполнении им трудовых обязанностей), имеет право обратного требования (регресса) к этому лицу в размере выплаченного возмещения, если иной размер не установлен законом.

Возникает ряд вопрос: Каким образом изменить сложившуюся правовую практику? Как обеспечить высокий уровень компенсации морального вреда, не ухудшая при этом материального положения медицинских работников? На наш взгляд, существует правовой институт, способный решить данную проблему.

Называется он страхование профессиональной ответственности медицинских работников. Появилась данная правовая конструкция еще в середине $60-\mathrm{x} г$ гг. $\mathrm{XX}$ в. в США, и суть ее заключалась в том, что врач не мог получить лицензию на осуществление медицинской деятельности до того момента, пока не будет застрахована его профессиональная ответственность.

Российская правовая наука неоднократно высказывалась о законодательном закреплении данного института. К примеру, в 2018 г. данную проблему обозначали в своей научной статье студенты Финансового университета при Правительстве РФ в городе Калуга С. А. Гзогян, Н. М. Саргасян под научным руководством кандидата экономических наук О. Н. Сусляковой [1].

Еще раньше, в 2006 г., профессор ИРГМУ Исаев в своей работе писал о необходимости создания нормативно-правового акта, содержащего в себе правила страхования профессиональной ответственности. Однако до сих пор соответствующего закона не существует.

\footnotetext{
${ }^{1}$ Решение № 2-456/2016 2-456/2016 M-413/2016 М-413/2016 от 8 июня 2016 г. по делу № 2-456/2016 // Судебные и нормативные акты РФ. URL: https://sudact.ru/regular/doc/ P8Dqawk7hyZh (дата обращения: 27.11.2019).Текст : электронный.

${ }_{2}^{2}$ Решение № 2-828/2017 2-828/2017 M-761/2017 М-761/2017 от 5 декабря 2017 г. по делу № 2-828/2017 // Судебные и нормативные акты PФ URL: https://sudact.ru/regular/doc/ JhDHLpQx8f64/ (дата обращения: 27.11.2019). Текст : электронный.
} 
В 2009-2010 гг. Общественный совет по защите прав пациентов при Росздравнадзоре совместно с Минздравом РФ подготовили два законопроекта:

1) законопроект «Об обязательном страховании гражданской ответственности медицинских организаций перед пациентами»;

2) законопроект «Об обязательном страховании пациентов».

Однако разработаны они были крайне плохо и подверглись серьезной критике в научной среде. В частности, в своей работе анализ вышеуказанных проектов провел доктор медицинских наук, профессор Клинического института им. Владимирского Алексей Анатольевич Старченко. До настоящего времени никаких положительных сдвигов в сторону доработки проектов либо подготовки новых не наблюдалось.

Единственная норма, затрагивающая страхование профессиональной ответственности, предусмотрена в подп. 7 п. 1 ст. 72 Ф3 «Об основах охраны здоровья граждан в РФ» ${ }^{1}$, согласно которой медицинские и фармацевтические работники имеют право на страхование риска своей профессиональной ответственности.

Как можем заметить, речь идет о праве, а не об обязанности, в остальном же отношения регулируются нормами о страховании предусмотренных гражданским законодательством и не содержат особенностей, характерных для медицинской деятельности. На основании вышесказанного приходим к следующим выводам:

1. Законодательное закрепление института обязательного страхования профессиональной ответственности врачей необходимо. Это поможет обеспечить своевременную и в большем размере компенсацию морального и материального вреда пациентам, при этом не ухудшая финансового положения медицинских работников. К примеру, полис от СПАО «Ингосстрах» обеспечивает страховое покрытие до 1 млн рублей, другие компании предлагают заключение договора на аналогичных условиях.

2. Нормы должны быть зафиксированы либо в отдельном федеральном законе (например, ФЗ «Об обязательном страховании профессиональной ответственности медицинских работников») либо путем внесения изменений в ФЗ «Об основах охраны здоровья граждан в РФ».

При этом следует законодательно закрепить правила страхования, условия договора с учетом специфики медицинской деятельности.

\section{Литература}

1. Гзогян С. А., Саргасян Н. М., Суслякова О. Н. Страхование профессиональной ответственности медицинских работников // Инновационная экономика: перспективы развития и совершенствования. 2018. № 8(34). Текст : непосредственный.

2. Исаев Ю. С., Воропаев А. В., Воропаев И. В. Страхование профессиональной ответственности медицинских работников // Сибирский медицинский журнал. 2006. № 2. Текст : непосредственный.

3. Старченко А. А. Законопроект «Об обязательном страховании гражданской ответственности медицинских организаций»: не защищает интересы ни пациента,

\footnotetext{
1 Федеральный закон «Об основах охраны здоровья граждан в Российской Федерации» от 21.11.2011 № 323-Ф3 // СПС «КонсультантПлюс». Текст : электронный.
} 
ни учреждения здравоохранения // Менеджер здравоохранения. 2012. № 10. С. 62-67. Текст : непосредственный.

4. Гордиенко М. М. К вопросу о введении обязательного страхования гражданской ответственности медицинских учреждений // Актуальные проблемы российского права. 2012. № 4. С. 92-100. Текст : непосредственный.

Статья поступила в редакциию 15.04.2021; одобрена после рецензирования 13.05.2021; принята к публикащии 22.06.2021.

\section{MORE ON IMPROVMENT OF HEALTH LAW}

Nikita A. Bogodukhov

Cand. for a Master's Degree,

Dorzhi Banzarov Buryat State University

6 Sukhe-Batora St., Ulan-Ude 670000, Russia

nikisbog@yandex.ru

Abstract. The article analyzes the relevant judicial practice on compensation for moral and material harm due to a medical error. We have carried out a comparative legal analysis of similar cases in foreign countries. The study revealed a conformity between the existence of an institution of compulsory professional liability insurance and the level of compensation for moral damage. We studied a number of draft laws, particular attention was paid to earlier scientific publications, since the discussed problem had been developed for a long time and many lawyers saw the same way of its solution. Taking into account the opinion of individual scientists, we pointed out the necessasity to issue a federal law, which would establish the obligation of medical workers to insure their professional responsibility, and regulate the relations arising in this connection.

Keywords: medical law, insurance, professional responsibility, medical workers, moral harm, compensation for harm, medical institutions, insurance law, medical institution, draft law

\section{For citation}

Bogodukhov N. A. More on Improvment of Health Law. Bulletin of Buryat State University. Law. 2021; 2: 26-30 (In Russ.).

The article was submitted 15.04.2021; approved after reviewing 13.05.2021; accepted for publication 22.06.2021. 